\title{
A morte e o além na Eneida
}

\author{
JOÃO PEDRO MENDES \\ Departamento de Filosofia \\ Instituto de Ciências Humanas \\ Universidade de Brasília
}

\begin{abstract}
RESUMO: Fronteira entre vida e morte. Natureza cíclica do fenômeno vida-morte-vida. O reino das sombras da morte na concepção dos antigos. A catábase do livro VI. Significação última da vida e da morte no pensamento e na arte de Virgílio, no âmbito das correntes místicas e filosóficas da Antiguidade. Palingênese das almas. Os vivos proporcionam aos mortos o simulacro de vida de que estes necessitam no Além. A Eneida como história de morte e de vida.
\end{abstract}

PALAVRAS-CHAVE: morte e Além na Antiguidade, misticismo e filosofia, mortevida em Virgílio, Eneida: vida e morte.

A fronteira entre a vida e a morte é a mais tênue de todas as fronteiras: um milímetro de curso do gatilho de uma arma de fogo, o fio invisível de uma lâmina, a picada micrométrica de uma agulha ou a mais fina parede da ampola de veneno letal. Na balança da vida e da sua negação ${ }^{1}$ o fiel pende à mais ligeira brisa.

Depois que um ser haure a centelha de luz que é a vida, começa inelutavelmente a parábola que ascende até voltar ao ponto inicial do não-ser. Do nada para o nada vai um "palmo de dia", na expressão do poeta eólico Alceu².

Não nos será difícil imaginar qual o impacto produzido no pathos do homem quando, nos alvores da história da civilização, se deparou com a perda irreversível de um semelhante. A reflexão virá suscitar duas indagações: tratar-se-á de uma aniquilação completa e definitiva? Esse fato será inevitável?

O homem primitivo sentia-se imerso no torvelinho cíclico do tempo, no jorro de luz que nasce, se dissipa e retorna ao amanhecer. Terá sido o primeiro sentimento de perda de um companheiro, ou de um inimigo abatido, que lhe abriu a perspectiva do "nunca mais", com a interposição do presente ao passado e ao futuro. Concluindo pela aniquilação definitiva, ele teria atingido assim a plenitude de consciência da morte. Daí à sensação de inanidade da vida é outro exíguo passo. E ao pessimismo impotente de uma visão trágica. Luz e escuridão, duas vertentes da mesma realidade crua. A noite é mãe da morte, e o sono seu irmão; como o dia é pai da vida, e a luz sua irmã.

O mais velho documento literário concernente à morte é a epopéia de Gilgamesh, cuja ação decorre no início do terceiro milênio a.C. Trata-se do primeiro relato que tem como protagonista um ser humano, e não uma divindade, sendo coetânea do aparecimento da escrita e da história. A certa altura, o herói sumério, que é rei de Uruk, "dois terços deus, um terço homem”, conforme se 
diz logo no começo, faz uma importante descoberta. Em sua luta para recuperar a plena divindade, destroçado pela doença fatal infligida por Astarte ao seu outrora feroz inimigo e agora inseparável companheiro Enkidu, reconhece sua própria condição de mortal. Tão horripilante e tétrica descoberta é contraposta à dor pungente causada pelo silêncio total e inquebrantável do amigo querido. A busca de Gilgamesh prossegue, concentrando-se agora em sondar os mistérios do outro lado da vida, mergulhado na angústia deprimente de saber que é efêmero (lit., "que dura um só dia”). Conhece pela primeira vez o medo e, em veemente apóstrofe, interroga (Heidel, 1946, 63-4):

\section{Que sonho estranho é esse que de ti se apoderou? \\ Submergiste na escuridão e já não me escutas mais! \\ Quando eu morrer, serei semelhante a Enkidu? A dor \\ entrou em meu coração, tenho medo da morte.}

Foi esse medo da morte que paradoxalmente impeliu o herói a novos cometimentos e aventuras para vencê-lo, e o levou a terras fantásticas, que se dissolvem na utopia e o deixam náufrago do nada. A morte é invencível, mas nada e ninguém conseguem impedir-lhe a ousadia de desafiá-la.

O homem descobriu os segredos da morte sem dúvida por etapas. A primeira deverá ter sido o reconhecimento de sua inevitabilidade. A porção de vida que a cada um cabe por destino (que os gregos chamarão de moira) é consumida por Gilgamesh na longa jornada em direção à prudência e à sabedoria, até tornar-se aquele que "era sábio, viu os mistérios e conheceu as coisas secretas". Neste poema épico, encontramos já os principais tópicos de reflexão sobre o fenômeno da volta ao pó da terra: temor e angústia, sentimento do caráter precário e inane da vida, atitude a tomar para suportar o império dessa cruel realidade. Nascer e viver para a morte lancinante e tétrico mistério, que os avanços da reflexão adensam cada vez mais, como se adensa o bosque impenetrável ao afoito explorador que insiste em devassá-lo.

Voltando-nos para o Egito e os documentos escritos, igualmente dos começos da história, é a sombra da morte que perpassa sobre os destroços dessa brilhante civilização. Os incontáveis espécimes do chamado Livro dos mortos revelam-nos alguns dos segredos que encobriam o misterioso trajeto das almas para além da vida. Trata-se de guias iniciáticos ou manuais de orientação da viagem do morto "para nascer para a eternidade", ritualmente depostos pelos sacerdotes nas múmias, entre amuletos a que se atribuíam estranhos sortilégios. Estavam escritos em papiro, iluminados de traços e figuras enigmáticos, que debruavam o texto formular de preces aos deuses e de palavras "abridoras das portas". Ante a múmia do finado, o oficiante salmodiava a "encomendação" e as ladainhas que o guiariam pelas regiões do mundo inferior empestadas de imundícies dos monstros devoradores de almas e entranhas, e de miasmas e emanações dos malditos ${ }^{3}$ Diante do tribunal dos deuses, no longo juízo da "noite da pesagem da alma", o morto tinha de justificar-se, após o que se transformava em morto-Osíris, sentindo rastejar em sua coluna dorsal a Serpente de fogo e passando a ter seu nome de eternidade e uma nova memória. Vinha a seguir a escalada do céu, rumo aos campos de Ialu, ou jardins afortunados. Ele era agora falcão do deus Hórus. Com seu olhar penetrante, estava apto a contemplar o Ovo cósmico, retentor da energia vibrátil originária da vida. Imerso na luz sotíaca que emana do cadáver - a mesma luz da Via Láctea, constitutiva do primeiro degrau da escada luminosa que ascende ao patamar da existência futura - e no olho de Rá, torna-se parcela do espírito indesdrutível animador do eterno recomeço do universo.

No mundo egeo-mediterrânico pré-helênico, circulou um turbilhão de idéias de lastro comum que emergiu de civilizações e culturas aparentemente diferenciadas. Do Oriente ao Ocidente, envolvendo o Egito, a Mesopotâmia e as regiões limítrofes dos Bálcãs, caldearam-se raças e crenças, por sobre o fundo existencial da condição humana. O problema da morte e da vida não estava ausente, antes pelo contrário, obsidiava grupos e indivíduos, que procuravam romper o 
círculo da fatalidade. A deusa-mãe geradora da vida é exatamente a mesma que traz a morte. Do pôr-do-sol com a extinção da luz, até ao nascer da aurora que a traz de volta, estende-se o reino da morte, o mundo inferior das sombras e ausências. O sono e o sonho noturnos são a anti-realidade simétrica da vida à luz do dia. O caminho da escuridão e do silêncio acompanha a trajetória percorrida pelo homem do berço ao túmulo. Será a via do ser para o não-ser? De modo quase sempre implícito, esta reflexão subtende as lucubrações dos filósofos pré-socráticos. O binômio vida-morte conjuga-se nas mudanças ou "viragens" do fogo (tropai pyrós), nas transformações do Uno que se oferece alternadamente como Mesmo e Outro, Igual e Diferente, numa contraposição não antagônica, mas complementar'.

Gerar e destruir, surgir e aniquilar são as molas propulsoras de tudo quanto é e não-é. O problema metafísico ser-devir equaciona-se com o problema gnosiológico razão-sensação. Empédocles de Agrigento vai recapitular os dados da questão, estabelecendo os quatro elementos de seus predecessores como arkhê. Duas forças - philia = amor; ekhthra/neikos =ódio/ discórdia - agitam continuamente esses elementos, devendo-se a elas todo o processo de conjunção, desenvolvimento e crescimento, por um lado, e de separação, diminuição e morte, por outro. Os pitagóricos viam nas oposições de números pares e ímpares o jogo dessas forças a um só tempo aglutinadoras e desagregadoras. Como, porém, no pitagorismo se mesclam os postulados de uma filosofia com os de uma religião, a tentativa de responder à questão da morte reside nas duas afirmações básicas de seu espiritualismo: sobrevivência e metempsicose.

O homem purifica-se progressivamente até escapar do ciclo dos nascimentos e mortes corporais. No fundo, o pitagorismo tenta explicar e satisfazer as exigências do problema moral, que reclama uma sanção rigorosa que discrimine bons e maus. Ora, é óbvio que tal sanção não pode ser aplicada em vida; daí se conclui pela necessidade de que a alma subsista depois da morte física. Os argumentos de Kant, em sua Crítica da razão prática, reivindicando a existência de um justiceiro post mortem têm aqui sua longínqua formulação.

Diz Cornford (1950, XVI) que "a consciência arrasadora da morte ensombrou profundamente as grandes correntes do pensamento grego". Entre os elos extremos dessas correntes medo avassalador e indiferença absoluta - existe espaço para todos os matizes. É gigantesca a distância de tempo e concepção que vai de Epicuro ("A morte não é nada com respeito a nós: quando existimos, ela ainda não existe; quando ela existe, nós já não existimos"s) até Sartre e Heidegger (angoisse, nausée; Angstgefühl, Qual): ante o pensamento da morte como naufrágio total de um ser que contempla o nada, irrompem instintivamente no homem a angústia ou a náusea. A existência humana estaria incontida nos limites de dois nadas: o antes e o depois.

Conta uma antiquíssima lenda ${ }^{6}$ que o sátiro Sileno, perseguido e capturado em terras da Frígia pelo rei Midas, respondeu assim à indagação deste sobre qual seria a coisa melhor e mais adequada para o homem: "Oh! raça maldita que dura um só dia, filha do azar e da miséria, por que me obrigas a te dizer o que seria conveniente não ouvires? A melhor coisa de todas te é absolutamente inacessível: não ter nascido, não ser, não ser nada. Depois disto, o melhor para ti será morreres depressa".

Nesta resposta vemos a aniquilação total como solução para o problema da existência: retornar ao nadà, ao não-ser, ao "Ser Único Absoluto" (Antero de Quental) ou Nirvana, onde imergem os indivíduos para dissolução da identidade que adquiriram ao nascer. A morte seria o castigo pela secessão dilacerante do ser coletivo e universal, o resgate do princípio de individuação, o regresso do múltiplo ao Uno. Anaximandro, no seu célebre fragmento, não falaria de outra coisa, segundo alguns intérpretes, ao evocar o tributo (dike e tísis, "castigo" e "retribuição") que uns seres pagam aos outros, pela sua injustiça (adikia), de acordo com o decreto (táxis) do tempo.

No pólo oposto situam-se os "filósofos do Jardim". Lucrécio, a mais de dois séculos de distância, invoca Epicuro como gênio da filosofia, para abordar o tema da morte, cujo temor é 
instilado nos homens pela ignorância da natureza da alma. Conclui o livro III do seu Da natureza das coisas declarando a sem-razão do medo e desespero ante o retorno ao estado que os corpos e almas tinham antes de nascer. Alma e corpo nascem e morrem ao mesmo tempo, desintegrandose nos mesmos átomos que haviam se ajuntado por intervenção do clinamen, para constituição do ser ${ }^{7}$. Um eco distante, porém com outro alcance, podemos ouvi-lo no título do capítulo XX do livro I dos Ensaios de Montaigne: "Filosofar é aprender a morrer", o qual, aliás, começa por citar Cícero $^{8}$. Este, por sua vez, cria na imortalidade da alma segundo a grandiosa construção platônica do mundo das Idéias. Pergunta o fundador da Academia (Fédon, 67c d): "Mas aquilo a que chamamos morte não é precisamente o fato de a alma e o corpo se separarem?", para rematar: "Ora, são os que se dedicam à filosofia os que mais zelo põem na libertação da alma, e o exercício a que se dedicam os filósofos é fazer que se efetue essa separação entre a alma e o corpo". A filosofia, aliás, é definida por Sócrates como "preparação para a morte" (thanatu meléte), sendo esta o seu "gênio verdadeiramente inspirador ou Musaguetes". Já que falamos de Platão, é bem conhecida a aversão que nutre pelos poetas, condenando em especial as suas descrições da morte como fonte de temores para a humanidade (República III, 386a-387b).

Já os estóicos vêem na morte uma necessidade, justificando até mesmo o suicídio, que reputam como único meio de impedir, em certos casos, a perda do bem maior, a virtude. Perante o dilema de perder a vida ou a sabedoria, optam pela primeira. Epicteto, neste ponto em conformidade com Epicuro, proclama que a morte em nada nos afeta: uden prós hemás. O mesmo filósofo do Pórtico, ainda segundo seu discípulo Arriano, chegava a exclamar: "Maldita seja a vida sem morte!" (katara esti to mê apothanein). O próprio Zeus, turbado e impaciente com os problemas de governo do Olimpo, invejaria a condição mortal do homem: a este, ao menos, vem Thánatos libertá-lo de seus sofrimentos...

A Tanatologia constituiu-se em torno do fato de a morte ser um assunto importante demais nas preocupações dos vivos, a ponto de impregnar a religião, as artes plásticas e cênicas, a literatura, numa palavra, a vida, a cultura e a ciência do homem ${ }^{10}$.

Nos poemas homéricos vislumbramos a concepção grega que atribuía a divindades superiores, ou a subalternas (daimones, entre theoi e héroes), o poder misterioso que aniquila. Apolo e Ártemis (o Sol e a Lua) encarnam essa potência máxima, talvez mediante personificação das forças que a imaginação popular atribuía a esses corpos celestes.

\section{A Catábase do livro VI da Eneida (vv. 268-899)}

No livro VI da Eneida, as naus troianas chegam às praias de Cumas, em solo itálico. É um momento de suspensão entre passado e futuro. Eneias precisa de definir seu rumo, uma vez mais. Faltam-lhe agora os conselhos oraculares de Anquises. Vai procurar transpor, com volta, a fronteira que divide o mundo dos vivos e dos mortos. Conjura a sacerdotisa de Apolo a conduzi-lo às mansões do Além, para encontrar-se com o velho pai. A Sibila, peremptória e intransigente, ergue obstáculos, mas o herói insiste e contra-argumenta com sua linhagem divina. Satisfeitas as exigências e cumpridos os rituais de lustração e sacrifícios aos deuses, um tremor de terra avisa que o caminho está livre. Na escuridão, através das mansões vazias e dos reinos de simulacros, vão descendo o herói e a sacerdotisa, até atingirem o Cocito. A barca de Caronte mal suporta o peso de um vivo na travessia do rio.

Passam depois por diversas regiões, a que Dante, em sua descrição do inferno, chamará de "círculos", numa clara alusão aos rituais iniciáticos dos mistérios eleusinos. Até chegarem ao termo da viagem, à presença de Anquises, numa campina inundada de luz purpúrea, com sol e estrelas próprios, povoada de homens notáveis - heróis, poetas, benfeitores da humanidade $^{11}$ — agora transmudados em sombras felizes, entregues a belas atividades de fruição dos regalos mais apetecidos durante a vida terrena ${ }^{12}$. O velho troiano, em sua contemplação, 
aponta e nomeia, entre as almas voltijantes como abelhas em torno da corrente do Leteu, aquelas que, depois de um longo ciclo de mil anos (cf. mito de Er, livro X da República de Platão), voltarão à terra, purificadas e regeneradas em novos corpos.

Eneias, já conhecedor de seu destino e do empreendimento que chefiava, volta ao mundo "superior" pela porta ebúrnea dos sonhos falazes, retemperado e de alma lavada pelo que viu e escutou no Além.

Estamos diante de um relato que tem precedentes na literatura, com modelo conhecido. A catábase de Eneias e da Sibila de Cumas à mansão dos mortos deve inspirar-se na célebre nékuia do canto XI da Odisséia e ter por fundo vetustas tradições médio-orientais. Reconhece SainteBeuve ${ }^{13}$ a dependência do Mantuano em relação ao modelo homérico, assinalando as diferenças, "que são ao mesmo tempo as das idades e as dos gênios", e declarando adiante: "Entre Homero e Virgílio, houve todo um trabalho do pensamento, da meditação e do tempo: houve Platão e o Fédon, os Campos Elísios de Píndaro e as descrições líricas, as iniciações, os sistemas filosóficos, o Sonho de Cipião, toda uma construção e uma arquitetura do mundo do Além, sem dúvida artificial e adquirida (...)" Compaginando as duas narrações, verifica-se o ecletismo "ondoyant" (Carcopino) de Virgílio, evocando "com a pena de um iniciado" (Mallinger, 1944, 155) um Hades mais de acordo com suas próprias concepções e, indubitavelmente, relacionado com a doutrina pitagórica acerca do mundo supra-humano (Mendes, 1985, 152).

Parece hoje razoavelmente estabelecida a filiação de Virgílio aos círculos pitagorizantes do século I a.C. "Em Roma, ninguém podia ser considerado instruído se não fosse pitagórico", escreveu Cícero num célebre passo das Tusculanas $(I, 1,16)$. À catábase da Eneida é impossível negar-se uma ligação com a "Descida de Pitágoras ao Hades", tal como a possuímos no que nos resta do Ábaris de Heraclides Pôntico, discípulo de Platão, cotejado com fragmentos de Jerônimo de Rodes e de Hermipo ${ }^{14}$. A katábasis de Pitágoras filiar-se-ia, por sua vez, na de Héracles, da qual seria apenas uma réplica.

$\mathrm{Na}$ época helenística, floresceu uma intensa literatura sobre lendas a respeito do filósofo de Samos, literatura essa que nos revela o profundo interesse de iniciados ou simples eruditos, os quais viam nas doutrinas do "homem-deus" uma resposta moral, religiosa e política aos problemas do seu tempo. Efetivamente, esses relatos maravilhosos evocavam ideais éticos filiados tanto ao platonismo academicista quanto aos ensinamentos pitagóricos propriamente ditos. Além do credo moral e religioso, dava-se muita importância à condução da vida social e política, tal como a teorizara e implantara Pitágoras em Crotona, cidade onde, à sua chegada, se opera uma prodigiosa revolução e nasce uma nova sociedade organizada em esquemas genuinamente comunitários. O sistema de vida e de governo expandiu-se em seguida pela Itália meridional, nomeadamente Metaponto, vindo a perder-se pela reação agressiva e destruidora das populações circunvizinhas.

Bastaria o livro VI da Eneida para elucidar-nos da enorme influência exercida em Roma pelos relatos prodigiosos de cunho filosófico e religioso inspirados no credo pitagórico e irradiados a partir dos centros do helenismo, sobretudo Alexandria.

A civilização grega invadira o mundo de então, acompanhando os exércitos ovantes de Alexandre e radicando-se nos quatro cantos do império por ele criado. Um dos terrenos mais férteis que lhe foi extremamente receptivo constituiu-o a comunidade judaica do Egito. A Diáspora havia propiciado aqui a formação de um núcleo importantíssino de judeus, cujo distanciamento do Templo de Salomão em Jerusalém dava azo a uma vida religiosa sui generis, aberta a influências estranhas e teologicamente mais liberal. Uma das influências marcantes, especialmente no domínio da escatologia, foi a do pitagorismo lendário, difundido pelos prosélitos do Mestre e pelos adeptos da Academia.

Nem Artapanos nem Fílon de Alexandria ou Flávio Josefo aludem a uma catábase de Moisés, embora contenham muitos elementos de um conto romanesco judaico-alexandrino sobre 
a vida do chefe hebreu redigido no início do século I a.C., ou provavelmente ainda antes. Nessa narrativa, a lenda do nascimento, infância, adolescência e vida adulta de Pitágoras é aplicada à biografia de Moisés, sobrepondo-se à descrita em quatro dos livros do Pentateuco. Os cenários dessa biografia são os mesmos do Mestre: Samos, Egito de Amásis, Itália do Sul e Sicília.

No ponto de encruzilhada e confluência de três mundos que foi Alexandria, o pitagorismo impregnou o que sobrevivia do antigo Egito, da Grécia clássica e das culturas sumério-assíriocaldaicas. O herdeiro maior desse legado helenista pitagorizante foi o império romano de Augusto, após os íntimos contactos do fim da república. E Virgílio, adepto militante do neoterismo, não ficou imune a essa onda pulsante que alastrava da capital do mundo helenístico. "De 60 a.C. até 50 d.C. [...], acadêmicos, estoicos, ecléticos, peripatéticos, todos, como outrora em Crotona, todos, mais menos, pitagorizavam" (Carcopino, 1944, 190). O exemplo mais elucidativo é o de Marco Túlio Varrão (116-27 a.C.), o maior teólogo do paganismo romano, segundo Sérvio, ao qual Plínio o Velho atribui como última vontade, igual à de muitos outros homens cultos: ser sepultado, conforme o ritual pitagórico, num ataúde de terracota, sobre um leito de folhagem de mirto, oliveira e álamo-preto (Mallinger, 1944, 155). Desses ritos fúnebres típicos do pitagorismo que apontam para os cuidados com os restos mortais, por certo servindo de contraponto à transmigração concomitante da alma para novo corpo, até a última reencarnação libertadora, é tentador imaginarmos a passagem definitiva para a morada no Além, com acenos no texto, há relativamente pouco tempo recuperado, de uma lâmina de ouro achada sobre um túmulo na Lucânia, em Petelia, hoje Strongoli. Trata-se de um pequeno roteiro que a alma do morto deveria seguir em sua peregrinação além-túmulo. Eis o precioso texto:

Acharás à esquerda das mansões do Hades uma fonte e, à beira dela, um alvo cipreste.

Não te aproximes dessa fonte.

Acharás uma outra, uma fonte de água fresca correndo do lago da Memória; diante dela estão guardiães.

Dirás tu: "Sou filha da terra e do céu estrelado;

minha origem é, portanto, celeste; sabei-o vós mesmos.

Estou cheia de sede e morrendo. Dai-me depressa

água fresca que corre do lago da Memória".

E eles te darão a beber a água do lago sagrado, e então reinarás com os outros heróis.

Ressuma destes versos algo de grave, solene e majestático, num clima de unção religiosa de romeiro do Além que, anelante, busca e encontra sua morada.

O poeta da Eneida já dera sobejas demonstrações de sua "iniciação" nas correntes místico-esotéricas em seus poemas da juventude. As Bucólicas também são um monumento ao Número dos pitagóricos, como penso ter ajudado a comprovar ${ }^{15}$. Nas Geórgicas existem igualmente fortes indícios (v. g. o episódio de Aristeu) de que ele rendia culto à numerologia e não ignorava o misticismo de Elêusis, do orfismo e até das religiões orientais, que empolgavam os círculos eruditos da capital do império romano.

As teorias da transmigração das almas que Platão seguramente estudou e conferiu, sobretudo em suas viagens ao sul da Magna Grécia, onde manteve íntimos contactos com prosélitos do pitagorismo, ocupavam as mentes e imaginações de pensadores e poetas latinos. Virgílio teve sob os olhos a esplêndida fabulação do mito de Er, o armênio, no já assinalado livro X da República. Tira daí proveito e exemplo para a grandiosa e bela descrição da palingênese das almas. Do filósofo da Academia recolhe também sua concepção de recompensas e punições consecutivas à morte. Mas é o conceito estoico de alma do mundo que empolga o nosso poeta. Esse conceito, aliás, deriva igualmente do platonismo. O fogo racional, lei imanente do universo, 
constitui os princípios vitais, as almas dos diversos entes, as razões seminais (lógoi spermatikoi) advogadas pelo estoicismo. Equivale ao Demiurgo platônico, ou ao Motor Imóvel aristotélico, primeiro agente do movimento de todos os seres. Com as já mencionadas idéias pitagóricas de transmigração das almas para outros corpos, completa-se o tríptico inspirador de Virgílio em sua descrição da palimpsicogenesia.

Nos versos 703-751 do livro VI, Eneias extasia-se com a multidão de almas que volitam sobre as margens do Leteu, adejando por entre as espículas de sarças rumorejantes de um bosque ermo e solitário. Impressionado, pergunta ao pai a razão desse mistério. Percorre-lhe o corpo um frêmito sagrado. Responde Anquises (vv. 713-15):
[...] Animae, quibus altera fato
corpora debentur, Lethaei ad fluminis undam
securos latices et longa obliuia potant.
[...] São as almas às quais o destino deve
um segundo corpo e que, ao longo do Leteu,
bebem das águas calmas e dos longos olvidos.

No himeneu da razão com a fantasia - quintessência da arte maior do Mantuano e de todo grande poeta - é agora a vez da indagação ou do questionamento filosóficos (vv. 719-21):

$O$ pater, anne aliquas ad caelum hinc ire putandum est

sublimis animas iterumque ad tarda reuerti

corpora? Quae lucis miseris tam dira cupido?

Meu pai, será que existem almas que vão daqui até o céu

e que voltam de novo à espessura dos

corpos? Que avidez de luz é essa que têm os infelizes?

Anquises revela ao filho os arcanos do princípio espiritual que anima o cosmos e todos os seres (spiritus intus). Expõe-lhe também a origem e o destino das almas, que somente depois de purificadas retornarão ao fogo celeste e etéreo. Nessa absorção será total a perda da memória, podendo então rever a abóbada celeste mediante a reentrada, volvidos mil anos, em novos corpos. E o ciclo se repete sem fim, como se a vida de um novo ser dependesse inelutavelmente da morte de um predecessor. Tudo no cosmos caminha da vida para a morte, ou da morte para a vida - só muda o sentido, já que a realidade tem duas faces inseparáveis. Do não-ser não pode proceder o ser, a menos que se inclua um "termo" médio. Na linguagem poética de Virgílio que recobre seu profundo sincretismo filosófico-religioso, isso é possível. Esse termo médio é o corpo (velho e caduco, decomposto, mas ainda assim corpo). Da época em que se plasmou a formação é característica a busca desse sincretismo filosófico-religioso, que se esforçava por encontrar racionalidade nas intuições e experiências místico-religiosas, e misticismo e religiosidade nas doutrinas filosóficas.

Nos rituais da morte dos povos primitivos, comprova-se facilmente a intenção dos vivos se manterem em contacto com os mortos, proporcionando-lhes o "simulacro de vida de que [estes] necessitam no Além" ${ }^{16}$. Ainda hoje, certas tribos da África e de outros continentes depositam alimentos, roupas e objetos à beira dos túmulos de seus entes queridos. Homenageiam os mortos e os auxiliam no Além com um "suplemento de vida" (André, 1983/4,197). É sugestiva a reaproximação de milênios de história, se voltarmos às concepções presentes na epopeia de Gilgamesh: no cume dos zigurates, construções piramidais de adobe, em degraus, moravam os deuses, que eram abastecidos de alimentos e vestes pelos homens das cidades, para que pudessem "subsistir", mesmo sendo imortais.

A Eneida é um poema de reis, combates, soldados e generais. É um poema, por conseguinte, de morte e de vida, de vencidos e vencedores. O herói Eneias recebeu a missão de transplantar Tróia para longínquas paragens. De ressuscitar das cinzas da destruição e da morte um império 
vivo. E tudo à custa de vitórias e derrotas - mais duas faces da mesma realidade. Também o herói protagonista tem duas faces. Aquela que o imortalizou - e à sua obra de fundador - é a da glória de lançar os fundamentos da nova Tróia. A outra ${ }^{17}$ é a do anti-herói, ou melhor, a das lacrimae rerum, e a da dura ciência de que elas mentem mortalia tangunt ${ }^{18}$. Já foi posto em relevo que Eneias é o único herói épico que, logo no início da ação, a coisa que mais apetece é a morte. Uma espécie de herói à força (I, 97-8):

[...] mene Iliacis occumbere campis

non potuisse tuaque animam hanc effundere dextra, saeuos ubi Aeacidae telo iacet Hector [...]!

[...] Ah, por que não pude eu morrer nos campos de Ílio

e derramar esta alma sob os golpes de tua mão,

lá onde jaz o indômito Heitor, sob o dardo do Eácida [...]!

Por diversas outras vezes, ao longo do poema, Eneias deseja e até chega a pedir a morte. E não por cobardia. Na derradeira e trágica noite de Tróia, quando (II, 354)

Vna salus uictis nullam sperare salutem[.]

Uma salvação têm os vencidos: não esperar salvação nenhuma[.],

e o sacerdote Panto lhe grita que tudo terminou (II, 325):

[...] Fuimus Troes, fuit Ilium et ingens

gloria Teucrorum [...]

[...] Acabamos, nós os troianos, acabou Ílio e a imensa

glória dos teucros [...]

- ele nem assim obedece, resistindo até à consumação de tudo e incitando os companheiros ao sacrifício supremo (II, 353):

[...] Moriamur et in media arma ruamus!

[...] Morramos, atirando-nos no meio das armas!

Recebe de Heitor, farrapo humano, a divina injunção de partir e edificar a nova Tróia; só começa a vacilar ante a visão macabra dos destroços do velho Príamo, símbolo da pátria destroçada (II, 557-8):

[...] lacet ingens litore truncus

auolsumque umeris caput et sine nomine corpus.

[...] Jaz ali na praia um tronco enorme,

e uma cabeça, arrancada dos ombros, e um corpo inominado.

"Profunda inanidade da glória!", exclama Walter de Medeiros em seu comentário (ibid. 90), que adiante prossegue:

"Mesmo na hora da suprema exaltação patriótica, quando Anquises mostra a Eneias a revoada dos heróis nascituros, mesmo nessa hora, a última figura traz a fronte envolvida em uma sombra agoireira. É um jovem de dezanove anos, mas está condenado pela inveja dos deuses" (ibid., 90-91).

O jovem é Marcelo, que os fados mal irão mostrar à terra (ostendent terris hunc tantum fata, VI, 869). "Se nem a piedade tem poder para esquivar a morte, bem se compreende a dolorosa surpresa do herói perante o alvoroço das almas que se preparam para regressar ao lastro dos corpos:

Quae lucis miseris tam dira cupido?

porquê, nesses desventurados, um almejo tão sinistro da luz?

"Momento de horror na poesia antiga: Aquiles, no mundo dos mortos, suspirava pela luz do alto; Eneias, que tanto sofreu na vida, maravilha-se de que alguém pretenda regressar a ela. 
'Desventurados', 'almejo sinistro da luz': palavras tremendas, sem dúvida. Não pode ser-se mais pessimista nem menos 'mediterrânico'." (Id., ibid., 91)

O troiano Eneias terá de fazer a guerra com todas as crueldades e malas-artes das guerras, Mas ele é pius, ostenta e pratica a rainha das uirtutes que ornarão o comportamento dos futuros descendentes dos troianos. Inexplicavelmente, porém, vai cometer o ato brutal que fecha a Eneida inacabada: não poupa o vencido (Anquises, em veemente e profética apóstrofe aos romanos, diz na célebre sinédoque (VI, 851-3):

\section{Tu [...], Romane, memento}

parcere subiectis [...]

$\mathrm{Tu}[\ldots]$, romano, sê atento

a poupar os vencidos [...].

E Turno apelou para a clemência do vencedor e a extinção dos ódios e ressentimentos. Afinal, quem é Eneias? - “Augusto, sem dúvida, na intenção geral geral do poema. Mas também Antônio, em Cartago; Heitor, vitorioso de Aquiles-Turno, no Lácio. E a outra face? O homem do passado, o homem das lágrimas, o homem da incerteza e da angústia, o homem das frustrações, o homem da vitória igual a derrota?... Madame Bovary c'est moi, dizia Flaubert. Eneias é, de algum modo, o próprio Virgílio. Se penso no rosto do herói, não o vejo com a luz hierática e o queixo voluntarioso de Augusto, mas como a Virgílio representaram no mosaico de Hadrumeto, com aquelas faces cavadas, aqueles olhos cheios de uma flama sombria, aquela fronte virada para um futuro cógnito e distante."

"Virgílio acreditava que mais longe, para além do éter, mais tarde, para além do tempo, o sangue e as lágrimas do infeliz hão de florir em sóis. Então a morte terá a face da Vida — porque ambas terão a face do Amor." (Id., ibid., 94)

O tema da vida e da morte perpassa ao longo do poema como um todo. Nos dois episódios destacados (katábase do livro VI e morte de Turno do livro XII) ambas se entrelaçam em íntimo conúbio. O momento supremo da jornada imposta a Eneias pelo destino é, paradoxalmente, uma descida às profundezas nevoentas da terra (res alta terra et caligine mersas, v. 267). Antes de iniciá-la, sobe ao templo de Apolo - sugestão do fenômeno da vida - chegando depois à fronteira dos dois mundos., fronteira de dois mundos. A Sibila acompanha-o e testemunha o rito de travessia das sacra ostia, escancaradas noite e dia, mas num único sentido: da luz para as trevas (regna inuia uiuis, passagem proibida aos vivos). Chegam às fauces empestadas do Averno (fauces graue olentis Auerni, v. 201). Viandantes do Além, vão deixando para trás os vagidos das criancinhas mortas ao nascer, que choram por não terem haurido a doce luz, os condenados à morte por falsa acusação, os suicidas que invejam agora a mesma luz da vida que livremente extinguiram, os "Campos das Lágrimas" onde penam os consumidos por duras paixões de amor. Prosseguem até aos Campos Elísios, meta da viagem. Reconfortado pelo pai e suas profecias, Eneias retorna ao mundo dos vivos.

O episódio culminante que fecha a Eneida e recobre, ao que parece, a intenção última do poeta, apresenta-nos mais um quadro de suspensão entre os domínios da vida e da morte. Após increpar Turno por sua demora e hesitação em travar combate, o herói lança-lhe a fatal admoestação contida no dilema: subir até aos astros inacessíveis, ou refugiar-se nas entranhas da terra (XII, 892-3):

\section{[...] opta ardua pinnis}

astra sequi clausumue caua te condere terra.

O símile do sono irmão das morte e contraposição da vida é utilizado pelo poeta para realçar, mais uma vez, a impotência paralisante do rútulo ante o destino. Num brevíssimo retrospecto 
que é lampejo de luz recapitulador do seu passado, Turno revolve no coração mil pensamentos sobre o seu povo e a cidade, e não avista mais nem o carro nem a innã que segura a s rédeas. A uis tragica atinge o clímax na cena derradeira. Turno personifica a um só tempo todos os obstáculos à fixação na Itália e a sujeição definitiva à superioridade neotroiana. Tudo sugere que o pius Aeneas vai ceder às súplicas do vencido. A sensibilidade do poeta lançou mão desse recurso para de certo modo atenuar a crueza do golpe fatal. No tênue limite dos mundos da vida e do Além, incumbe ao romano a suprema imposição. O direito de vida e morte é apanágio do detentor do sumo poder. Ai dos que ousarem resistir! O dístico final da Eneida marca bem a força dramática da ruptura daquele limite (XII. 951-2):

\section{[...] Ast illi soluuntur frigore membra uitaque cum gemitu fugit indignata sub umbras.}

[...] O frio da morte gela-lhe os membros,

e sua alma indignada escapa gemendo para o reino das sombras.

e projeta intensa luz sobre a condição humana, tal como é concebida por Virgílio. O homem é um ser frágil ante o destino imposto pelos deuses tanto a vencedores como a vencidos. Sua vida tem duração breve e irreparável (breue et inreparabile tempus / omnibus est uitae, X.467-8). O jovem e promissor Marcelo do final do livro VI terá seu futuro ceifado pelo capricho dos fata aspera (v. 882); o rei dos rútulos, destroçado e ansioso por viver, nem implorando clemência foge a esse mesmo destino comum.

Essa a tragédia do homem, ser de fronteira do Aquém e do Além.

\section{Notas}

1 - O símile da balança está na Ilíada VIII, 66-7, onde Zeus pesa os dois destinos (kêr) que "derrubam as pessoas": de um lado, o dos troianos; do outro, o dos aqueus, que tremem ao ver o dia fatal e são dominados por um "terror lívido".

2 - "Bebamos! Por que esperamos as lucernas? Não há mais / que um palmo de dia." (fr. 346 LobelPage)

3 - Anúbis, ou "Reajustador de ossos", toma-o pela mão e condu-lo à presença de Osíris, a fím de se cumprirem os ritos da psicostasia.

4 - Cf. Sousa, 1975, passim.

5 - Laércio, X, 125.

6 - Aristóteles (Eudemo, fr. 6 Walzer) apresenta esta mesma afirmação. Mas foram os órficos que a adotaram como sua, atribuindo-lhe o significado de que a vida corpórea é uma prisão para a alma, com vistas à expiação das culpas. O texto mais explícito, contudo, é o de Teógnis de Mégara (v. 424 e ss.): "De todas as coisas, a melhor para nós, seres terrestres, seria / não nascer e não ver nunca mais os raios vivos do sol;/uma vez nascidos, o melhor seria transpormos o mais cedo possivel / o limiar do Hades e jazer sepultados sob grande massa de terra".

7 - Lucrécio diverge de Epicuro apenas num ponto: para nos tornar aceitável a morte, pinta a vida com as cores mais sombrias.

8 - Cícero (Tusculanae disputationes, I, XXX): "A vida inteira dos filósofos, como diz Sócrates, é uma "meditação sobre a morte". Montaigne, perto da morte, já não acredita nesta máxima, a qual também foi comentada por Erasmo, em seu Elogio da loucura. (Cf. Essais, in Oeuvres complètes, 1962, p. 1-1097.)

9 - Schopenhauer, p. 463.

10 - Acerca do problema da sobrevivência do homem no Além — problema distinto do da morte enquanto objeto de temor, assim como do problema do destino da existência, sobretudo para 
os que não crêem na imortalidade - é gigantesco o acervo de estudos publicados. William James, em 1896, referiu numa de suas conferências em Ingensol que a bibliografia de W. R. Alger: A critical history of the doctrine of a future life, 1879, se compunha de mais de cinco mil títulos! (Apud Jacques CHORON, La mort et la pensée occidentale, 1969, p. 8).

11 - Sainte-Beuve, 1891, 168 e ss., lamenta que o Mantuano haja omitido, na galeria dos "poetas, dos sábios, dos benfeitores do mundo, dos mortais divinos e harmoniosos", uma referência ao vulto de Homero, "esse pai e esse deus de toda a poesia". O lugar de honra foi dado ao mítico Museu, coevo de Orfeu. Quanto ao Sonho de Cipião, no livro VI da República de Cícero, o "contacto ultraterreno não é uma descida aos infernos, como as de Orfeu e a de Eneias, mas uma ascensão às esferas celestes, as quais são a verdadeira pátria da alma" (COSTA, 1978, p. 132).

12 - Sobre a imagem do Além como lugar de delícias, transposto da realidade da vida, cf. PEREIRA, 1955, sobretudo pp. 27, 29, 43, 67, 193-197 e 202.

13 - Vd. nota 11, supra.

14 - Transcrito por Diógenes Laércio, VIII, 40.

15 - Plínio (Historia naturalis, XXXV, 160): "Qui et defunctos esse multi soliis condi maluere sicut M. Varro Pythagorico modo in myrti et oleae atque populi nigrae foliis".

16 - Vd. nota 14 , supra.

17 - Na sequiência imediata desta citação, acompanharemos de perto as reflexões do eminente mestre de Coimbra.

18 - Eneida, I, 462: "Há lágrimas para o infortúnio, e a condição mortal do homem comove os corações".

\section{Referências Bibliográficas}

ANDRÉ, Carlos Ascenso. Morte e Vida na Eneida. Humanitas XXXV-XXXVI: 105-148, Coimbra, 1983/1984.

BELLESSORT, André. Introduction.Virgile, Énéide.Paris: Les Belles Lettres, 1966/1967.2v.

CARCOPINO, Jérôme. La Basilique pythagoricienne de la Porte Majeure. Paris: L'Artisan du Livre, 1944.

CHORON, Jacques. La mort et la pensée occidentale. Paris: Payot, 1969.

CICÉRON. Tusculanes. Ed. G. Fohlen. Paris: Les Belles Lettres, 1931.

CLAUSEN, Wendell. An interpretation of the Aeneid. Harvard studies in classical philology v. 68, p.139-147, 1964.

CORNFORD, F. M. Greek religions tought. Boston: Beacon Press, 1950.

COSTA, Aída. Temas Clássicos. São Paulo: Cultrix/Secretaria da Cultura, 1978.

DAREMBERG, Ch., SAGLIO, Edm., e POTTIER, Edm. Dictionnaire des antiquités grecques et romaines. Paris: Hachette, $1877-1918$, t. $3,2^{\circ}$ p. s.v.

DIOGENES LAERTIVS. Vitae Philosophorum, X.125, por H. S. Long. Oxford University Press, 1964.

EDWARDS, P. Heidegger and death. A critical evaluation. La Salle, 1980.

GRUMMOND, W. W. DE. Aeneas despairing. Hermes, v. 105, p. 224-234, 1977.

HEIDEL, A. The Gilgamesh epic and the old testament parallels. Chicago University Press, 1946.

JANKÉLÉVITCH, Vladimir. La mort. Paris: Flammarion, 1977. 
LOTZ, J. B. Tod. In: W. Brugger (dir.). Philosophisches Wörterbuch. Friburg, 1967, p. 387-388, s.v. LUCRÈCE. De la nature. Paris: Les Belles Lettres, 1978/1975. 2v.

MALLINGER, Jean. Pythagore et les mystères. Paris: Éditions Niclaus, 1944.

MEDEIROS, Walter de Sousa. A Outra Face de Eneias. Humanitas, Coimbra, v. 33-34, p. 81-94, 1981/1982.

MENDES, João Pedro. Construção e Arte das Bucólicas de Virgílio. Brasília: Editora Universidade de Brasília/INL, 1985.

MONTAIGNE. Essais. In: Oeuvres complètes. Paris: Bibliothèque de la Pléiade, 1962, p. 1-1097.

MORIN, Edgar. L' homme et la mort. Paris: Éditions du Seuil, 1970.

NIETZSCHE, F. Ecce Homo. In Obras completas, vol. IV. Buenos Aires: Ediciones Prestigio, 1970.

PEREIRA, Maria Helena da Rocha. Concepções Helénicas de Felicidade no Além. De Homero a Platão. Coimbra, 1955.

PERRET, Jacques. Les compagnes de Didon aux enfers (Aen. 6, 445-449). Revue des Études Latines. Paris, v. 42, p. 247-261, 1965.

PERRET, Jacques. Optimisme et tragédie dans l' Énéide. Revue des Études Latines. Paris, v. 45, p. 342-362, 1977.

PLATÃO. República. Trad. Maria Helena da Rocha Pereira. $3^{\mathrm{a}}$ ed. Lisboa: Fundação Calouste Gulbenkian, 1980.

PLÍNIO. Ed. J. Sillig. Gotha, 1853-55. 5v.

PROPÉRCIO. Die Gedichte des Properz. Berlim: T. Rundschau, 1918.

SAINTE-BEUVE. Étude sur Virgile. Paris: Calmann Lévy, Éditeur, 1891.

SCOPENHAUER, Arthur. On Death and Its Relation to the Indestructibility of Our Inner Nature.

In:-, The world as will and representation. Trad. E. F. J. Payne. Clinton: The Falcon's Wing Press, 1958. Cap. 41.

SOUSA, Eudoro de. Horizonte e Complementariedade. São Paulo: Duas Cidades/Editora Universidade de Brasília, 1975.

TOLSTOI, Lev Nikolaevich. The death of Ivan Ilich and other stories. Nova York, The New Amlibr., 1960.

MENDES, J. P. Death and afterlife in the Aeneid. Classica, São Paulo, 7/8: 141-152, 1994/1995.

\footnotetext{
ABSTRACT: The frontier between life and death. The cyclic nature of life-deathlife, the kingdom of the shadows of the dead in antiquity. The katabasis in Book VI. The ultimate meaning of life and death in the art and thought of Virgil in the context of classical mysticism and philosophy including the rebirth of souls. The living provide the dead with the semblance of life which they need in the other world. The Aeneid, as a story of life and death.

KEY WORDS: death and afterlife in antiquity, mysticism and philosophy, life + death in Virgil, Aeneid: life and death.
} 